\title{
ASSESMENT OF THE SOIL UREASE RESPONSE TO SULFONYLUREA HERBICIDES BASED ON STATISTICAL MODELS
}

\author{
Borozan, A. B..$^{1 *}$ - LALESCU, D. V. ${ }^{1}-$ Misca, C. D. ${ }^{1}-$ TrofiM, A. ${ }^{2}-$ HorablaGA, M. ${ }^{1}-$ \\ BORDEAN, D. M. ${ }^{1}-$ POPESCU, S. ${ }^{1}-$ MANEA, D. ${ }^{1 *}$ \\ ${ }^{1}$ Banat's University of Agricultural Sciences and Veterinary Medicine "King Michael I of \\ Romania” from Timisoara, Calea Aradului 119, 300645 Timisoara, Romania \\ (phone: +40-0256-277-082; fax: +40-0256-200-296) \\ ${ }^{2}$ Institute for Research and Innovation, Department of Psycho Biotechnology, State University \\ of Moldova, Alexei Mateevici 60, Chisinau, Moldova \\ (phone: +37-3069-953-996) \\ ${ }^{*}$ Corresponding authors \\ e-mail: borozan_a@yahoo.com; manea_dn@yahoo.com; phone: +40-0256-277-082
}

(Received 23 $3^{\text {rd }}$ Apr 2020; accepted $13^{\text {th }}$ Aug 2020)

\begin{abstract}
The aim of this paper was the evaluation of the ecotoxic effects of three sulphonylurea compounds, commonly used as herbicides against weeds in agriculture by mathematical models. The tests were performed both in laboratory and field conditions to study the changes in soil urease, considered a key enzyme for regulating soil nitrogen transformation and a sensitive indicator to herbicides. Mathematical models accurately reproduced the behavior of urease from chemically treated soil samples, based on real, observable processes. Besides, they simplify the view regarding the activity of the selected enzyme, as there are many factors and complicated biogeochemical processes, which might interfere. Overall, we conclude that, for the cambic chernozem model analyzed here, the normal (label-recommended) chlorsulfuron and amidosulfuron doses do not perturb soil urease activity and the former compound is more urease-friendly than either amidosulfuron or tifensulfuron. In the context of the long-term use of these herbicides, our research underlines the importance of mathematical models and the prefiguration of a map for the differentiation of field / laboratory experiments, for the most accurate highlighting of the biochemical imbalances caused by the chemical substances, the risk of overdose and the toxicity risk for soil and environment.
\end{abstract}

Keyword: ecotoxic effect, soil enzymes, chlorsulfuron, amidosulfuron, tifensulfuron

\section{Introduction}

Mathematical modeling can be used for developing scientific understanding and to test the effect of changes in a system (Marion and Lawson, 2008). The role of the mathematical models is to replicate the behavior of analyzed samples based on real observable facts (Ledder, 2013). Thus, information on the effect of herbicides on enzymes provides anticipations regarding the management of phytotoxic effects and the quality of soil, surface and groundwater. The researchers use all kinds of mathematical models for predictions related to soil herbicides influence, essential for agronomic purposes and for the protection of the environment (Swarcewicz and Gregorczyk, 2013; McGrath et al., 2019). In this context, information on the reaction of enzymes in the presence of herbicides is essential, as they are catalysts of their degradative processes. Sulfonylurea herbicides are a class of herbicides that have become extremely popular in recent decades due to their broad-spectrum weed control (He et al., 2012) at relatively low doses, i.e., between 20 and $200 \mathrm{~g} \mathrm{ha}^{-1}$ good crop selectivity, low mammalian toxicity, but they inhibit the enzyme acetolactate synthase (ALS) (Powles and Qin, 2010). These compounds and 
their metabolites can persist for a long time in natural environments, exert a phytotoxic effect (Mehdizadeh et al., 2016), and also affect the activity of soil microorganisms and enzymes (Yang et al., 2007; Radivojević et al., 2014).

However, there is surprisingly little information about the effects of sulfonylurea herbicides on soil enzymes although their measurement can provide us with relevant data about the agroecosystem health and anthropic-induced soil disturbance (Kiss, 2001).

Soil enzymes are intimately involved in organic matter and nutrient cycle in the pedosphere, actively participate in the transformation and decomposition of herbicides at this level, and contribute to the stabilization of soil structure. These enzymes are generally considered as relevant markers for assessing the degree of soil virginity in terms of changes induced by anthropogenic factors (Taylor et al., 2002; Riah et al., 2014). Therefore, the soil enzymatic potential serves as a suitable and subtle indicator of soil biological equilibrium (Lizy Sravanthi et al., 2015), health (Pankhurst, 2006), fertility (Piotrowska-Dlugosz, 2014), and quality (Lone et al., 2014), and is widely used to assess the hazard that herbicides pose on soil biological functioning (Sebiomo, 2011).

The activities of certain soil enzymes, including dehydrogenase, $\beta$ glucosidase, cellulase, urease, amidase, phosphatase, and arylsulphatase are used alone or coupled to calculate soil health indexes because their measurement involves simple procedures and provides an early warning system for disturbance in soil ecosystems (Shukla and Varma, 2011).

Urease from soil is of microbial and plant origin (Rathore and Nollet, 2012; Hameed et al., 2019), is persistent due to its association with organic and inorganic soil colloids (Baboo et al., 2013) and hydrolyzes urea (commonly used as a nitrogen source for plants).

The European Food Safety Agency has recently emphasized the lack of standardized methods for evaluating the ecotoxicity of herbicides and the pressing need for developing microbial markers sensitive to herbicide exposure (Thiour-Mauprivez et al., 2019). Urease activity is sensitive to herbicide application (Hameed et al., 2019), which in undisturbed soils tends to remain relatively constant over time (Conway and Pretty, 2013). Hence, it can be used for monitoring soil quality (Srinivasulu and Rangaswamy, 2014) and there is also relevant evidence that certain sulfonylurea herbicides can interfere with it (Thiour-Mauprivez et al., 2019).

However, its decrease reduces urea hydrolysis, which is beneficial because it helps keep nitrogen in a form less predisposed to levigation, i.e., ammonium ions $\left(\mathrm{NH}_{4}^{+}\right)$, (Schuster and Schroeder, 1990).

The aim of this study was to investigate the effect of three routinely used sulfonylurea herbicides, that is chlorsulfuron (CLS), amidosulfuron (AMS), and tifensulfuron (TIS), on soil urease activity, by using a mathematical model. In this context, understanding the response of urease activity in presence of herbicides can serve to assess and predict the overdose-related risks in terms of enzymatic potential, biochemical processes, especially the imbalances in the nitrogen circuit in which urease plays a key role, soil microbial biodiversity and toxic effects on the environment. The use of high doses in laboratory models and reporting to field conditions is essential because, according to Sofo et al. (2012), doses above the recommended application rates they can induce long-term disturbance in soil microbial and enzymatic activities, thereby disrupting the natural biochemical balance of the soil.

As a result, a thorough understanding of the effect of sulfonylurea herbicides on soil urease activity is of great interest for optimizing the use of such herbicides, as well as for limiting the potential risks associated with it. 


\section{Materials and methods}

\section{Experimental design}

The phytopharmaceutical products considered in this study were: (1) chlorsulfuron (CLS); (2) amidosulfuron (AMS) and (3) tifensulfuron (TIS), (Table 1).

Table 1. Phytopharmaceutical substances used in the experiment (Fluka ChemikaBioChemika 1995/1996, 1995; Manea et al., 2017)

\begin{tabular}{|c|c|c|}
\hline Herbicide substance & Chemical structure & $\begin{array}{c}\text { Manufacturing } \\
\text { company }\end{array}$ \\
\hline $\begin{array}{c}\text { Chlorsulfuron } \\
\text { (2-chlor-/N/4-methoxy-6- } \\
\text { methyl-1,3,5-triazine-2-il/- } \\
\text { aminocarbonyl/- } \\
\text { benzosulfonamide) }\end{array}$ & $\begin{array}{l}-\mathrm{SO}_{2} \mathrm{NHCONH} \\
\mathrm{Cl}\end{array}$ & $\begin{array}{c}\text { Du Pont de Nemours, } \\
\text { USA }\end{array}$ \\
\hline $\begin{array}{c}\text { Amidosulfuron } \\
(3-(4,6- \\
\text { dimethoxypyrimidin-2-yl)- } \\
1-(\mathrm{N}-\text {-methyl-N- } \\
\text { methyl)sulfonyl)urea })\end{array}$ & $\mathrm{CH}_{3} \mathrm{SO}_{2}-\underset{\mathrm{CH}_{3}}{\mathrm{~N}}-\mathrm{SO}_{2} \mathrm{NHCONH}-$ & AgrEvo, Germany \\
\hline $\begin{array}{l}\text { Tifensulfuron } \\
\text { carboxylate of methyl- } \\
\text { 2(methoxy-4-methyl-6- } \\
\text { triazine-1,3,5 yl-2) amino- } \\
\text { carbonyl amynosulfuronyl- } \\
3 \text { thiophene }\end{array}$ & $\mathrm{CH}_{3}$ & Nemours, SUA \\
\hline
\end{tabular}

For each herbicide, four doses were considered, irrespective of experimental conditions: (1) control (M); (2) normal dose (ND): chlorsulfuron, $20 \mathrm{~g} \mathrm{ha} \mathrm{h}^{-1}$; amidosulfuron, $60 \mathrm{~g} \mathrm{ha}^{-1}$; tifensulfuron, $60 \mathrm{~g} \mathrm{ha}^{-1}$; (3) two-fold normal dose (2ND): chlorsulfuron, $\mathrm{g} \mathrm{ha}^{-1}$; amidosulfuron, $\mathrm{g} \mathrm{ha}^{-1}$; tifensulfuron, $\mathrm{g} \mathrm{ha}^{-1}$; (4) five-fold normal dose (5ND): chlorsulfuron, $100 \mathrm{~g} \mathrm{ha}^{-1}$; amidosulfuron, $300 \mathrm{~g} \mathrm{ha}^{-1}$; tifensulfuron, $300 \mathrm{~g} \mathrm{ha}^{-1}$. Such doses have been often reported to occur in arable soils on which these herbicides have been applied. It was considered that the normal dose is the quantity recommended by the manufacturer for agricultural practices.

To provide relevant results, a cambic chernozem was considered in the present work. It is one of the most fertile soil types from Romania (Ianos et al., 1997) and covers important areas in Romania and eastern European countries (Hardarson and Broughton, 2013). The physico-chemical parameters of the 0-20 centimeters $(\mathrm{cm})$ soil horizon, wherein most microbial activity generally occurs (Shukla and Varma, 2011), were: coarse sand - particles less than $2 /$ millimeters $(\mathrm{mm})$ and greater than $0.2 \mathrm{~mm}$ in diameter, $0.5 \%$; fine sand - particles between $0.2 \mathrm{~mm}$ and $0.02 \mathrm{~mm}$ in diameter, 29.2\%; silt - particles between $0.02 \mathrm{~mm}$ and $0.002 \mathrm{~mm}$ in diameter, 29.2\%; clay - particles less than $0.002 \mathrm{~mm}$, 41.4\%; texture, clay loam; porosity, 49\%; hygroscopic coefficient, 9.2\%; pH, 6.45; humus content, $4.09 \%$; total nitrogen, $0.156 \%$ per gram dry weight soil; assimilable 
phosphorus content, $21.80 \mathrm{~g} / 100 \mathrm{mg}$ soil; assimilable potassium content, $29.70 \mathrm{~g} / 100 \mathrm{mg}$ soil.

The field study was conducted in the experimental fields of the Banat University of Agricultural Sciences and Veterinary Medicine "King Michael I of Romania" from Timisoara (BUASVMT). The experimental area $\left(45.45^{\circ}\right.$ lat. N, $21.14^{\circ}$ long. E, Timisoara, Romania) lies in the Banat silvo-steppe and is characterized by a temperate climate with Mediterranean influences, which is specific to the South-western Romania (Micu et al., 2015). The herbicides were applied in spring (May) according to the manufacturer's recommendations. For each treatment, the experiments have run in triplicate on experimental plots of $18 \mathrm{~m}^{2}$ each. Five random samples from the $0-20 \mathrm{~cm}$ soil horizon were collected using a trowel along a diagonal transect across each plot at 30 days after herbicide application. They were put in self-sealing sterile plastic bags, transported to the lab during the same day and homogenized in batches in a Waring blender (about 1,200 $\mathrm{g}$ per each herbicide treatment). Then, the humidity was adjusted to $15-17 \%$ by addition of distilled water, following the method described by Stefanic (2006) and the soil samples were maintained under controlled temperature $\left(t=25^{\circ} \mathrm{C}\right)$ for 48 hours to ensure a proper equilibration of the soil microflora.

The laboratory study was performed at the Laboratory of Soil Microbiology from BUASVMT. Before herbicide application, untreated samples collected from the field plots (as shown above) were transported to the lab and treated with herbicides (kept for 7 days), to facilitate soil-microbiota-herbicide interaction (triplicate per each treatment).

\section{Method for determining soil urease activity}

At the end of both studies, the soil samples were homogenized in batches (using a Waring blender) and sieved to remove coarse materials (e.g., roots, rocks, macro-organic matter) and particles larger than $2 \mathrm{~mm}$. Next, they were analyzed for determining the soil urease activity by adapting the method routinely used in Romania for this purpose (Stefanic, 2006). Briefly, reaction mixtures consisting $5 \mathrm{~g}$ of soil and $10 \mathrm{ml}$ of a $1 \%$ urea solution were incubated at $28^{\circ} \mathrm{C}$ for 24 hours, then treated with $70 \mathrm{ml}$ of a $0.1 \mathrm{~N}$ potassium sulfate solution, $2 \mathrm{ml}$ of $25 \%$ Seignette salt solution and $10 \mathrm{ml}$ of Nessler reagent [778333-7, Merck 13-773]. The absorbance was measured at $425 \mathrm{~nm}$ and the corresponding calibration curve was created using a $0.002 \%$ ammonium chloride solution. The soil urease activity (UA), expressed as micrograms of ammonium nitrogen per kilogram soil dry weigh ( $\mu \mathrm{g} \mathrm{NH}_{4}{ }^{+} / \mathrm{g}$ sol d. wt), was calculated according to the formula (Eq. 1):

$$
\mathrm{U} . \mathrm{A} .=\frac{E p \bullet C \bullet F \bullet 100 \bullet K U}{E e t \bullet V \bullet G}
$$

where $E p$ defines the sample extinction, Eet the reference solution extinction, $C$ the concentration of reference solution ( 0.01 micrograms of ammonia permilliliter, i.e., $\mu \mathrm{g}$ $\left.\mathrm{NH}_{4}^{+} / \mathrm{ml}\right), F$ the volume of the liquid from the filtrated soil $(80 \mathrm{ml}), V$ the volume of filtrate transferred in a sterile polyethylene tube $(50 \mathrm{ml}), G$ the mass of fresh soil $(\mathrm{g})$, and $K U$ the adjusted coefficient of soil humidity.

\section{Statistical analysis and mathematical modeling}

Data analysis was performed using Excel and the statistical packages PAST software version 2.17 and MVSP version 3.22 (Hammer et al., 2001). 
Planned pair wise comparisons between the reference and different treatments were conducted using Duncan's tests to determine the effect of herbicides on soil urease activity. The $p$ values lower than 0.05 were considered significant. The results were expressed as mean values with standard deviation (SD). Finally, we performed a cluster analysis to identify what herbicides and doses exert the lowest impact on soil urease activity. The data were hence classified in four groups, one including the values measured for the control group, and three other groups, one for each herbicide investigated. The constrained Ward's method was used since it allowed us to join the resulting such that increase in within-group variance is minimized.

The role of the mathematical models is to replicate the behavior of analyzed samples based on real observable facts (Ledder, 2013).

\section{Results and discussion}

The present study significantly broadens our understanding of side effects associated with the use of sulfonylurea herbicides in agriculture, and moreover, demonstrates for the first time that AMS and TIS can interfere with soil urease activity (Table 2; Figs. 1-3). Our results clearly show that the application of normal (label-recommended) dose of CLS and AMS tends not to perturb this enzymatic index in cambic chernozems, irrespective of experimental conditions.

This is supported by other scientists, who have found that, in most cases, the application of herbicides at recommended doses does not affect or has a reduced effect on soil enzymatic activity (Nannipieri, 1994; Utobo and Tewari, 2015). Moreover, this effect can be counteracted over time via absorbtion of herbicides onto soil colloids and stabilization of microbiota structure (Rao et al., 2010).

The measured values for soil urease activity in both experiments were shown in Table 2. The application of CLS and AMS under field conditions had no consistent effect on soil urease irrespective of dose (in all cases, $p>0.05$ ). In the case of TIS, there was, however, a marked inhibition of soil urease for the ND and 5ND treatments (in both cases, $p<0.05$ ), but not for the 2ND treatment (in both cases, $p>0.05$ ).

Table 2. Mean (and SD) for soil urease activity

\begin{tabular}{c|c|c|c|c|c|c|c|c}
\hline Treatment & \multicolumn{4}{|c|}{ Field conditions } & \multicolumn{4}{c}{ Laboratory conditions } \\
\hline \multirow{2}{*}{ M } & & ND & 2ND & 5ND & & ND & 2ND & 5ND \\
& 30.09 & & & & 28.36 & & & \\
CLS & $(1.26)$ & & & & $(3.29)$ & & & \\
& & 28.24 & 30.94 & 31.90 & & 28.27 & 32.96 & 25.89 \\
AMS & & $(2.86)$ & $(4.93)$ & $(4.28)$ & & $(3.48)$ & $(2.54)^{*}$ & $(4.83)$ \\
& & 33.61 & 28.92 & 26.89 & & 28.00 & 31.11 & 28.27 \\
TIS & & $(5.04)$ & $(1.02)$ & $(2.65)$ & & $(1.72)$ & $(2.06)^{*}$ & $(5.23)$ \\
& & 27.80 & 31.30 & 28.78 & & 33.20 & 27.37 & 35.22 \\
\hline
\end{tabular}

Legend: $\mathrm{M}$-control, $\mathrm{CLS}=$ chlorsulfuron, $\mathrm{AMS}=$ amidosulfuron, TIS = tifensulfuron, ND - normal dose, 2ND - two-fold normal dose, 5ND - five-fold normal dose. Marked boxes $\left(^{*}\right)$ indicate significant differences as compared to the reference group (Duncan's test, $\mathrm{p}<0.05$ )

This variations may be the result of the influence of soil physical and chemical properties (Šantric et al., 2018), but also because the microflora and enzymes are mostly absorbed on soil colloids, and direct contact with the herbicide may to be accidental (Stefanic, 1981). For this reason, in order to have a more complete picture of the influence of herbicides, 
experiments were performed both in the field and in the laboratory, testing other doses in addition to the usual dose for agricultural practice. We also consider that spatial and temporal variations of physical, chemical, microbiological, and biochemical proprieties of soil may be involved (Gimsing et al., 2004).

At similar levels, TIS, by contrast, caused significant, but low changes in urease activity for both experiments. Therefore, both CLS and AMS at the recommended dose appear to be more urease-friendly than TIS when dealing with this type of soil.

The variance of soil enzymatic activity in response to herbicide application was constant. This is in line with the results derived from other studies (Rasool et al., 2014; Tomkiel et al., 2014; Kumar et al., 2018). The soil enzymatic response can be also influenced by the presence of biological substrates, such as certain sulphonylureas herbicides, like thifensulfuronmethylor metsulfuron-methyl, and various metabolic products (Belhadj-Tahar et al., 2003).

Under field conditions, different CLS and AMS treatments did not consistently influence soil urease. Several field studies revealed that, depending on the dose, state of the enzyme (intracellular or extracellular enzymes, adsorbed on clay or humic acids), soil type (Šantric et al., 2018), and post-exposure duration, CLS can either inhibit or stimulate the activity of this enzyme (Yang et al., 2006). The measured values returned to normal levels 30 days posttreatment (Sofo et al., 2012), which is consistent with our findings.

Interestingly, TIS tended to significantly inhibit the soil urease activity, thus maintaining nitrogen in a less mobile (levigable) form. As a result, one can expect that field application of this herbicide may temporarily help in preserving the total nitrogen $(\mathrm{N})$ stocks in cambic chernozems. There is also likely that the effect of herbicide application may affect nitrogen biodisponibility in soil (Palma et al., 2016).

When compared to the control group, the use of CLS under laboratory conditions caused a significant increase in soil urease activity for the 2ND treatment $(p<0.05)$, but no consistent effect for the other two treatments $(p>0.05)$. A similar trend was observed for AMS (ND: $p>$ 0.05, 2ND: $p<0.05,5 \mathrm{ND}: p>0.05)$. In contrast, TIS showed a marked elevation in soil urease activity for the ND treatment $(p<0.05)$ and the 5ND treatment $(p<0.05)$, but no significant effect was found the second highest dose, i.e., the 2ND treatment ( $p>0.05)$.

However, in laboratory environments, which are conducive to intense microbial activity by providing ideal temperature and humidity conditions, TIS could be decomposed to thiophene metabolites that can increase the bioavailability of soil nickel, cobalt, and manganese via chelation, and therefore, stimulate soil urease activity. This is in agreement with the laboratory results obtained in this work after TIS application at ND and 5ND doses.

The dendrogram obtained by applying hierarchical cluster analysis to field data (Fig. 1A) revealed for AMS the greatest distance to the other groups, whereas the CLS, TIS, and M groups clustered closely together, with CLS appearing to exert the lowest impact on soil urease. However, a different trend was seen under laboratory conditions (Fig. 1B). The first cluster contained the measured values for the M, AMS, and CLS groups. A high similitude between CLS and AMS effects on this enzymatic index was observed. The second cluster was distinct and corresponded to soil samples exposed to TIS. 

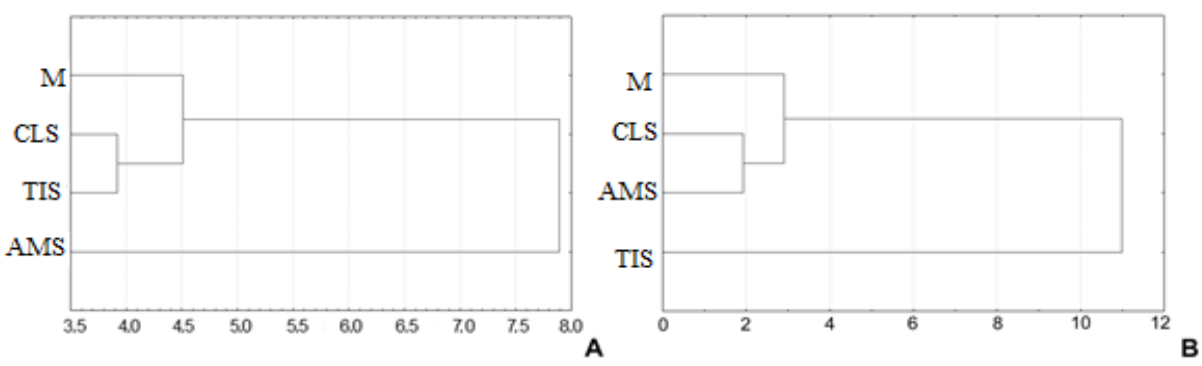

Figure 1. Cluster analysis using the Ward's method on urease activity in a cambic chernozem model exposed to AMS - amidosulfuron, $C L S$ - chlorsulfuron, TIS - tifensulfuron. Experiments were conducted under field conditions (A) and under laboratory conditions (B), M-control

Although all herbicides examined have structurally related heterocyclic rings and side groups bound to their positions 4 and 6, we observed different clustering patterns under field and laboratory conditions. Thus, the CLS behavior was similar with that of TIS under field conditions and with that of AMS under laboratory conditions. Field conditions, with considerable swings in humidity and temperature, are expected to induce a more variable response of soil urease to sulfonylurea herbicides as compared to those encountered in controlled laboratory environments. Therefore, the microbiological decomposition of these herbicides may be slower or even follow different pathways under such conditions, and as a consequence, potentially lead to different toxicity manifestations and effects. Such differences seem to occur especially in the case of TIS, which showed a marked inhibitory effect on soil urease in field experiments, but a consistent stimulatory action in laboratory tests.

Overall, our results confirm that these herbicides can either stimulate or inhibit the soil enzymatic activity (Micuti et al., 2018), but significant changes can occur in field conditions only when usual doses are exceeded or when optimal conditions of temperature and humidity promotes soil microbial activity (Pankhurst, 2006).

After cumulating the results of field and laboratory experiments, it was found that, in the case of CLS and AMS overdose, only one out of four treatments caused significant changes in enzymatic activity (as compared to the corresponding controls).

In contrast, such a situation was seen for TIS in two out of four treatments. Moreover, CLS was the only herbicide which in both experiments was clustered the closest to the reference group. As a result, it serves as the most urease-friendly sulfonylurea herbicide among the compounds investigated even in the case of overdose.

Water is essential for preserving the catalytic activity of soil enzymes, while both, soil moisture and temperature serve has the main factors responsible for soil biochemical and microbial characteristics (Giacometti et al., 2013). By applying the generalized linear model mathematical method, we found that urease activities in response to applying CLS (Fig. 2A), AMS (Fig. 2B) and TIS (Fig. 2C) decrease with moisture reduction. This highlights the importance of soil moisture for soil microorganisms, pesticide application (Kavita and Geeta, 2014), and organic matter turnover in soil (Borowik and Wyszkowska, 2016). In fact, it was demonstrated that for soil moisture $20 \%$ from the maximum water capacity, the soil enzymatic activity increases for urease, dehydrogenase, acid phosphatase, alkaline phosphatase, $\beta$-glucosidase and arylsulfatase. The increase in soil moisture and temperature can improve the mineralisation rate of sulphonylurea compounds, thus reducing their toxicity to soil microbiota, observation confirmed by literature data (Wang et al., 2010). In contrast, any decrease in soil moisture has a negative 
effect on these mineralisation processes (Wang et al., 2007). These data indorse the validity of our mathematical model (Fig. 2). Soil humidity equilibrium is essential for maintaining the soil microbiota homeostasis, since both excessive moisture and drought can reduce soil biomass (Landesman and Dighton, 2010).

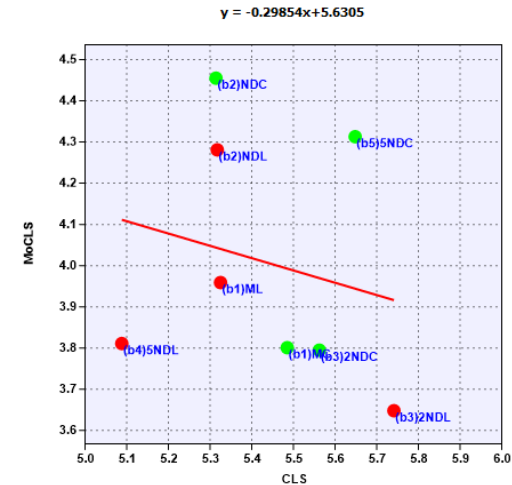

A. Variation of CLS correlated with samples moisture content using data square-root transformed, normal distribution and identity function

$$
y=-0.29854 \cdot x+5.6305
$$

Where $\mathrm{x}=$ CLS

$$
\mathrm{y}=\mathrm{MoCLS}
$$

Slope a: -0.29854

Interc.b: $5.6305 ; \mathrm{p}($ slope $=0): 0.8662$

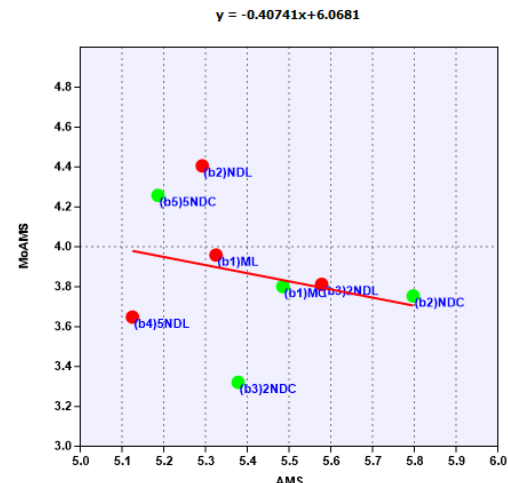

B. Variation of AMS correlated with samples moisture content using data square-root transformed, normal distribution and identity function

$$
y=-0.40741 x+6.0681
$$

Where $\mathrm{x}=$ AMS

$$
\mathrm{y}=\mathrm{MoAMS}
$$

Slope a: -0.40741

Interc.b: $6.0681 ; \mathrm{p}($ slope $=0): 0.8134$

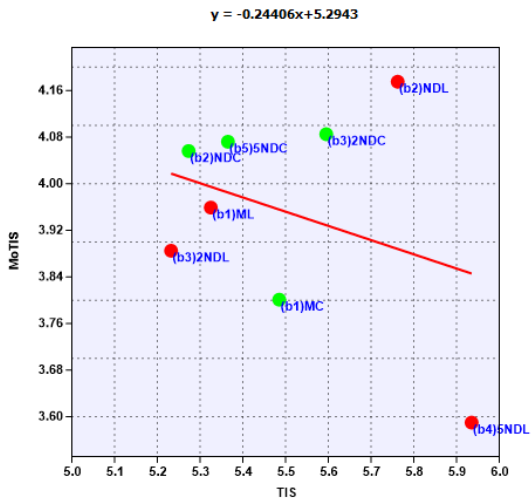

C. Variation of TIS correlated with samples moisture content using data square-root transformed, normal distribution and identity function

$$
y=-0.24406 \cdot x+5.2943
$$

$$
\begin{aligned}
\text { Where } \mathrm{x} & =\text { TIS } \\
\mathrm{y} & =\text { MoTIS }
\end{aligned}
$$

Slope a: -0.24406

Interc.b: $5.2943 ; \mathrm{p}($ slope $=0): 0.8715$

\section{Figure 2. Generalized linear models}

Legend: red = laboratory data (doses of herbicide used to treat soil samples in laboratory conditions), green = field data (doses of herbicide used to treat soil samples in field conditions), $C L S=$ chlorsulfuron, $A M S=$ amidosulfuron, $T I S=$ tifensulfuron, $M o C L S=$ moisture content in the soil treated with chlorsulfuron chlorsulfuron, MoAMS = moisture content in the soil treated with amidosulfuron, MoTIS = moisture content in the soil treated with tifensulfuron, end termination " $L "=$ laboratory condition, end termination " $C "=$ field condition, (b1) $M=$ control, $(b 2) N D=$ normal dose, $(b 3) 2 N D=$ two-fold normal dose, $b 5(5 N D)=$ five-fold normal dose

Soil urease is humidity - dependent and as soil moisture increases from $\theta 60$ to $\theta 100$, the rate of urea hydrolysis decreases by $13.9 \%-28.7 \%$, even if temperature and nitrogen decomposition rate remain. 
CLS samples show the smallest differences between laboratory and field results, followed by AMS and TIS (Fig. 3). The small differences observed here in urease activity for CLS may reflect the adaptation of bacterial communities to CLS, leading to strains capable of degrading this herbicide (Zanardini et al., 2002). Indeed, the last studies of Ergüven (2017), provide support for such a possibility.

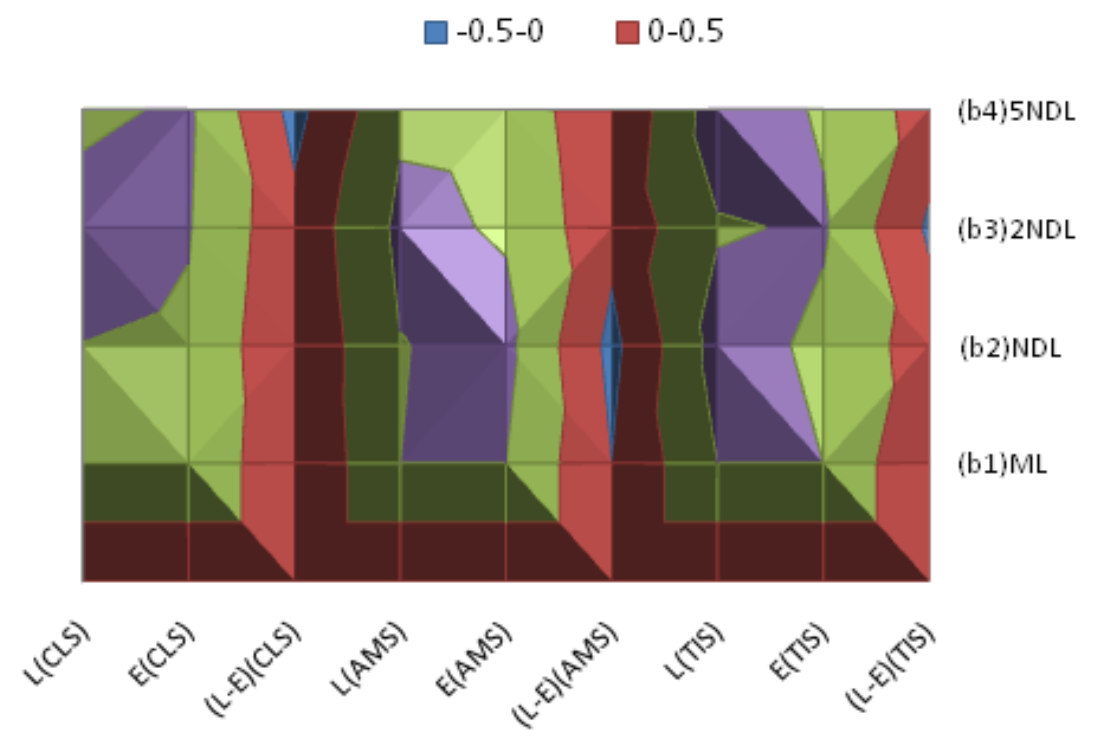

Figure 3. MAP of differences between Laboratory and Field Experiments

Legend: $L=$ laboratory, $E=$ Field Experiment, $(L-E)=$ differences between laboratory data and field experiment data, $C L S=$ chlorsulfuron, $A M S=$ amidosulfuron, $T I S=$ tifensulfuron, end termination " $L "=$ laboratory condition, end termination " $C$ " = field condition, (b1) $M=$ control, $(b 2) N D=$ normal dose, $b 3(2 N D)=$ two-fold normal dose, $b 5(5 N D)=$ five-fold normal dose

Based on the current results, we suggest that, among the sulfonylurea herbicides investigated, TIS and CLS have the greatest, and respectively, the lowest potential to affect the soil urease activity. However, further studies are necessary in order to expand on these findings and to elucidate the risk significance of these results. These considerations are also supported by Rachedi et al. (2018) who have recently showed that repeated application of herbicides causes major perturbations of soil biological activities.

\section{Conclusions}

In conclusion, the results of the present study suggest that CLS application on cambic chernozems is more urease-friendly than that of either AMS or TIS. It was also found that the CLS-treated soils were always clustered the closest to the untreated soils.

By applying the generalized linear model mathematical method, we found that urease activities in response to applying CLS, AMS and TIS decrease with moisture reduction. In addition, demonstrated that there are slight differences between the activity of urease in soil samples treated with CLS (laboratory and field), followed by AMS and TIS.

The applied statistical models accurately reproduced the urease response in the presence of sulfonylurea herbicides. Their evaluation can predict the risks related to 
overdose, both in terms of the enzymatic potential and the impact on urea function, as well as the consequences on soil and environment.

This approach provides a way for soil and crop management and can be extended to other herbicide classes for the purpose of ecological risk assessment. The study can be extended with the evaluation of herbicide residues in the soil, to know the risks involved in the applied doses and mobility of herbicides and the occurrence of possible accumulations and bio concentrations with risk on the environment and humans.

It is also recommended that further research should extend the trials on several soil types, with the development of databases which include the reaction of these herbicides on specific soil areas, to ensure that farmers have a clear picture and make informed decisions.

Acknowledgments. We are grateful to Professor dr. Gergen Iosif and to Eng. Nica Dragos for constructive comments and recommendations. In addition, the first author (ABB) wishes to thank Professor dr. Stefanic Gheorghe for continuous support throughout her scientific career. The research is supported by the project "Ensuring excellence in the activity of RDI within USAMVBT" code 35PFE, submitted in the competition Program 1 - Development of the national system of research - development, Subprogram 1.2 - Institutional performance, Institutional development projects - Development projects of excellence in RDI.

\section{REFERENCES}

[1] Baboo, M., Pasayat, M., Samal, A., Kujur, M., Maharana, J. K., Patel, A. K. (2013): Effect of four herbicides on soil organic carbon, microbial biomass-c, enzyme activity and microbial populations in agricultural soil. - Int. J. Res. Environ. Sci. Technol. 3(4): 100112.

[2] Belhadj-Tahar, H., Adamczewski, N., Nassar, B., Coulais, Y. (2003): Toxicovigilance: New biochemical tool used in sulfonylurea herbicides toxicology studies. - Acta Pharm. 53: 111-118.

[3] Borowik, A., Wyszkowska, J. (2016): Soil moisture as a factor affecting the microbiological and biochemical activity of soil. - Plant Soil Environ 62(6): 250-255.

[4] Conway, G. R., Pretty, J. N. (2013): Unwelcome harvest: agriculture and pollution. Routledge, London.

[5] Ergüven, G. Ö. (2017): Tekirdağ Ziraat Fakülte si Dergisi. - Journal of Tekirdag Agricultural Faculty 14(02): 110-118.

[6] Fluka Chemie AG (1995): Fluka 1995/1996: Chemica Analytika BioChemica Analytika. Fluka Chemicals, Switzerland.

[7] Giacometti, C., Demyan, M. S., Cavani, L., Marzadori, C., Ciavatta, C., Kandeler, E. (2013): Chemical and microbiological soil quality indicators and their potential to differentiate fertilization regimes in temperate agroecosystems. - Applied Soil Ecology 64: $32-48$.

[8] Gimsing, A. L., Borggaard, O. K., Jacobsen, O. S., Aamand. J., Sørensen, J. (2004): Chemical and microbiological soil characteristics controlling glyphosate mineralization in Danish surface soils. - Appl Soil Ecol 27: 233-42.

[9] Hameed, A., Al-Rashida, M., Uroos, M., Uroos Qazi, S., Sadia Naz, S., Ishtiaq, M., Khan, K. M. (2019): A patent update on therapeutic applications of urease inhibitors (2012-2018). - Expert Opinion on Therapeutic Patents 29(3): 181-189.

[10] Hammer, Ø., Harper, D. A. T., Ryan, P. D. (2001): PAST: Paleontological Statistics Software Package for Education and Data Analysis. - Palaeontologia Electronica 4: 1-9. 
[11] Hardarson, G. G., Broughton, W. J. (eds.) (2013): Molecular microbial ecology of the soil. Results from an FAO/IAEA Coordinated Research Programme, 1992-1996. - Springer Science \& Business Media, Berlin.

[12] He, Z., Liu, D. H., Li, R. H., Zhou, Z. Q., Wang, P. (2012): Magnetic solid phase extraction of sulfonylurea herbicides in environmental water samples by Fe3O4@dioctadecyl dimethyl ammonium chloride@ silica magnetic particles. - Anal. Chim. Acta 747: 29-35.

[13] Ianos, G. I., Pusca, I., Goian, M. (1997): Soils Banat - natural conditions and fertility. Mirton Publishing Timisoara, Romania (Solurile Banatului - conditii naturale si fertilitate. - Editura Mirton Timisoara, Romania).

[14] Kavita, R., Geeta, D. (2014): Bioremediation and biodegradation of pesticide from contaminated soil and water - A noval approach. - Int. J. Curr. Microbiol. App. Sci 3: 2333.

[15] Kiss, S. (2001): Advances in soil enzymology (Parts I-III). - Stud. Univ. Babeş-Bolyai, Biol 46(1): 3-48.

[16] Kumar, A., Imran, M., Kumar, S. P. J., Kumar, M., Singh, A. N., Srivastava, A. K. (2018): Assessment of Soil Urease Activity and its Kinetic Parameters in Chilli Rhizosphere under the Influence of Pesticides. - Biopestic. Int. 14(1): 47-57.

[17] Landesman, W. J., Dighton, J. (2010): Response of soil microbial communities and the production of plant-available nitrogen to a two-year rainfall manipulation in the New Jersey Pinelands. - Soil Biology and Biochemistry 42: 1751-1758.

[18] Ledder, G. (2013): Mathematical Modeling. - In: Mathematics for the life sciences: calculus, modeling, probability, and dynamical systems (Chapter 2). Springer Science \& Business Media, pp. 84-143.

[19] Lizy Sravanthi, P., Madhuri, T., Subramanyam, D., Suvarnalatha, D., Suvarnalatha, D. P. (2015): Effect of cartap hydrochloride on amylase and cellulase enzyme activities in agricultural soil. - International Journal of Life Sciences 4(1): 44-47.

[20] Lone, A. H., Raverkar, K. P., Pareek, N. (2014): In-vitro effects of herbicides on soil microbial communities. - The Bioscan 9(1): 11-16.

[21] Manea, D. N., Henegar, M., Andru, M., Ienciu, A. A. (2017): Codex of plant protection products approved for use in Romania (part I, II). $-4^{\text {th }}$ Edition Andagra SRL Arad. Printed by S.C. Carmel Print $\gamma$ Design SRL (Codexul produselor de protectie a plantelor omologate pentru utilizare in Romania (partea I, II), Editia a IV-a Andagra SRL Arad. Tipar executat de SC Carmel Print $\gamma$ Design SRL).

[22] Marion, G., Lawson, D. (2008): An introduction to mathematical modelling. - Edinburgh: Bioinformatics and Statistics Scotland, University of Bristol.

[23] McGrath, G., Rao, P. S. C., Mellander, P. E., Kennedy, I., Rose, M., Van Zwieten, L. (2019): Real-time forecasting of pesticide concentrations in soil. - Science of the Total Environment 663: 709-716. https://doi.org/10.1016/j.scitotenv.2019.01.401.

[24] Mehdizadeh, M., Alebrahim, M. T., Roushani, M., Streibig, J. C. (2016): Evaluation of four different crops' sensitivity to sulfosulfuron and tribenuron methyl soil residues. - Acta Agric. Scand. Sect B 66: 706-713.

[25] Micu, D. M., Dumitrescu, A., Cheval, S., Birsan, M. V. (2015): Climate of the Romanian Carpathians. - Springer International Publishing Switzerland.

[26] Micuti, M. M., Bădulescu, L., Israel-Roming, F. (2018): Effect of Pesticides on Enzymatic Activity in Soil. - Bulletin UASVM Animal Science and Biotechnologies 75(2): 80-84.

[27] Nannipieri, P. (1994): The potential use of soil enzymes as indicators of productivity, sustainability and pollution. - In: Pankhurst, C. E., Doube, B. M., Gupta, V. V. S. R., Grace, P. R. (eds.) Soil Biota: Management in Sustainable Farming Systems. CSIRO, East Melbourne.

[28] Palma, G., Jorquera, M., Demanet, R., Elgueta, S., Briceno, G., de la Luz Mora, M. (2016): Urea fertilizer and $\mathrm{pH}$ influence on sorption process of Flumetsulam and MCPA acidic herbicides in a volcanic soil. - J. Environ. Qual. 45(1): 323-330. 
[29] Pankhurst, C. (2006): Effects of pesticides used in sugarcane cropping systems on soil organisms and biological functions associated with soil health. - Sugar Yield Decline Joint Venture, Adelaide.

[30] Piotrowska-Dlugosz, A. (2014): Enzymes. - In: Rao, L. G. M. A (ed.) Enzymes and soil fertility. OMICS eBook Group.

[31] Powles, S. B., Qin, Y. (2010): Evolution in Action: Plants Resistant to Herbicides. - Annu. Rev. Plant. Biol 61: 317-347.

[32] Rachedi, K., Zermanea, F., Tir, R., Ayachef, F., Durane, R., Laugae, B., Karamae, S., Simone, M., Boulahrouf, A. (2018): Effect of sulfonylurea tribenuron methyl herbicide on soil Actinobacteria growth and characterization of resistant strains. - Brazilian Journal of Microbiology 49: 79-86.

[33] Radivojević, L., Jovičić, D., Santrić, L., Găsić, S., Umiljendić Gajić, J. (2014): Effects of metsulfuron-methyl on soil microbial activity. - Arch. Tech. Sci. 11(1): 77-82.

[34] Rao, M., Scelza, R., Scotti, R., Gianfreda, L. (2010): Role of enzymes in the remediation of polluted environments. - J. Soil Sci. Plant Nutr. 10(3): 333-353.

[35] Rasool, N., Reshi, Z. A., Shah, M. A. (2014): Effect of butachlor (G) on soil enzyme activity. - Eur. J. Soil Biol. 61: 94-100.

[36] Rathore, S. H., Nollet, M. L. L. (eds.) (2012): Pesticides: Evaluation of environmental pollution. - CRC Press, London.

[37] Riah, W., Laval, K., Laroche-Ajzenberg, E., Mougin, C., Latour, X., Trinsoutrot-Gattin, I. (2014): Effect of pesticides on soil enzymes: a review. - Environ. Chem. Lett 12: 257-73.

[38] Šantric, L. J., Radivojevic, L. J., Gajic-Umiljendic, J., Saric-Krsmanovic, M., ĐurovicPejcev, R. (2018): The effects of nicosulfuron and glyphosate on microbial activity of different soils. - Planta Daninha 36: e018159989.

[39] Schuster, E., Schroeder, D. (1990): Side effects of sequentially and simultaneously applied pesticides on non-target soil organisms: Laboratory experiments. - Soil. Biol. Biochem 22: 375-383.

[40] Sebiomo, A., Ogundero, V. W., Bankole, S. A. (2011): Effect of four herbicides on microbial population, soil organic matter and dehydrogenase activity. - Afr. J. Biotechnol 10: 770-778.

[41] Shukla, G., Varma, A. (2011): Soil Enzymology. - Soil Biology book series (SOILBIOL volume 22), Berlin Heidelberg:Springer-Verlag.

[42] Sofo, A., Scopa, A., Dumontet, S., Mazzatura, A., Pasquale, V. J. (2012): Toxic effects of four sulphonylureas herbicides on soil microbial biomass. - Journal of Environmental Science and Health Part B 47(7): 653-659.

[43] Srinivasulu, M., Rangaswamy, R. (2014): Pesticides are usually applied simultaneously or one after another for crop protection, and this type of pesticide application often leads to a combined contamination of pesticide residues in soil environment (Chapter 5). - In: Gianfreda, L., Rao, M. A. (eds.) Enzymes and pesticides in Agricultural Sciences. OMICS Group e books [e-book].

[44] Stefanic, G. (1981): Researches concerning a biological index of soil fertility. - Fifth Symp. On soil Biol. Iasi, pp. 35-46.

[45] Stefanic, G. (2006): Problems of theoretical and applied agrophytotechnics. - XXVIII, ARDI Fundulea 28: 38-39. (Probleme de agrofitotehnie teoretica si aplicata, XXVIII, ICDA Fundulea 28: 38-39).

[46] Swarcewicz, M. K., Gregorczyk, A. (2013): Atrazine Degradation In Soil: Effects Of Adjuvants And A Comparison Of Three Mathematical Models. - Pest. Management Science 69(12): 1346-1350. Doi: 10.1002/Ps.3510.

[47] Taylor, J. P., Wilson, B., Mills, M. S., Burns, R. G. (2002): Comparison of microbial number and enzymatic activities in surface soils and subsoil using various techniques. Soil. Biol. Biochem 34(3): 387-401. 
[48] Thiour-Mauprivez, C., Martin-Laurent, F., Calvayrac, C., Barthelmebs, L. (2019): Effects of herbicide on non-target microorganisms: Towards a new class of biomarkers? - Science of The Total Environment 684: 314-325.

[49] Tomkiel, M., Wyszkowska, J., Kucharski, J., Bacmaga, M., Borowik, A. (2014): Response of microorganisms and soil enzymes to soil contamination with the herbicide Successor T 550 SE. - Environ Prot Eng 40(4): 15-27.

[50] Utobo, E. B., Tewari, L. (2015): Soil enzymes as bioindicators of soil ecosystem status. Applied Ecology and Environmental Research 13(1): 147-169.

[51] Wang, H. Z., Liu, X. M., Wu, J. J., Huang, P. M., Xu, J. M., Tang, C. X. (2007): Impact of soil moisture on metsulfuron-methyl residues in Chinese paddy soils. - Geoderma 142: 325-333.

[52] Wang, H., Xu, J., Yates, S., Zhang, J., Gan, J., Ma, J., Wu, J., Xuan, R. (2010): Mineralization of metsulfuron-methyl in Chinese paddy soils. - Chemosphere 78: 335-341.

[53] Yang, C., Sun, T., He, W., Chen, S. (2006): Effects of pesticides on soil urease activity. Ying Yong Sheng Tai Xue Bao 17(7): 1354-1356.

[54] Yang, C. L., Sun, T. H., He, W. X., Zhou, Q. X., Su, C. (2007): Single and joint effects of pesticides and mercury on soil urease. - J. Environ. Sci. 9: 210-216.

[55] Zanardini, E., Arnoldi, A., Boschin, G., D’Agostina, A., Negri, M., Sorlini, C. (2002): Degradation pathways of chlorsulfuron and metsulfuron-methyl by a Pseudomonas fluorescens strain. - Annals of Microbiology 52: 25-37. 